\title{
New GOLD COPD Guideline 2019: How We Deal With It? (Inhaled Corticosteroid Use and Blood Eosinophil Count)
}

\author{
Ari Julian Saputra*,1, Kiki Widyastuti ${ }^{1,2}$ Yusup Subagio Sutanto ${ }^{3}$ \\ ${ }^{1}$ Bukit Asam Medika Hospital, Tanjung Enim \\ ${ }^{2}$ dr. H. Moh. Rabain Regional Public Hospital, Muara Enim \\ ${ }^{3}$ Departement Pulmonology and Respiratory Medicine Faculty of Medicine, Universitas Sebelas Maret - \\ dr. Moewardi Hospital, Solo
}

\section{ABSTRACT}

Background: Blood eosinophils may predict response to inhaled corticosteroids (ICS) in chronic obstructive pulmonary disease (COPD), where ICS is recommended in patients at high risk of exacerbations by the Global Initiative for COPD (GOLD) strategy. It can help clinicians to estimate the likelihood of beneficial preventive responses to the addition ICS to regular bronchodilator treatment, and thus can be used as a biomarker in conjunction with clinical assessment when making decisions regarding ICS use. This study aims to compare therapeutic data with blood eosinophil count in COPD patients.

Method: Data were collected from consecutive COPD outpatients in Bukit Asam Medika Hospital starting from March $1^{\text {st }}, 2019$ until June $30^{\text {th }}, 2019$ and $d r$. H. Mohamad Rabain Hospital starting from Oct $1^{\text {st }}, 2019$ until Dec 27 $7^{\text {th }}, 2019$. We collected demographics, anthropometrics, smoking history, therapy, dynamic lung volumes, the Medical Research Council scale (MRC), CAT score, and blood eosinophil count.

Results: From 57 data collected, 24 patients $(42,1 \%)$ were having blood eosinophil count $\geq 300$. Patients who have more exacerbation in COPD Group C were $33,3 \%$ and $63,2 \%$ in COPD Group D. The proportions of ICS-treated COPD Group D patients and blood eosinophil count of $<300$ and $\geq 300$ was $63,9 \%$ and $36,1 \%$, respectively.

Conclusion: This study may provide information and characteristic of COPD patient in Indonesia rural area and showed who may have benefit to ICS therapy based on recommendation GOLD COPD 2019. Blood eosinophils counts is a low-cost biomarker and may help clinicians to made decision therapy.

Keywords: COPD, ICS, blood eosinophil count

*Correspondence: Ari Julian Saputra - arijulian94@gmail.com

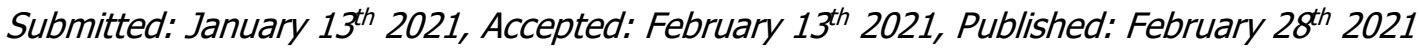




\section{INTRODUCTION}

Chronic obstructive pulmonary disease (COPD) is a leading cause of morbidity and mortality worldwide that induces an economic and social burden that is both substantial. In 2010, the number of COPD cases was 384 million with a global prevalence of $11,7 \%$. Globally, there are around three million deaths annually. ${ }^{1-4}$

Exacerbations in COPD are major contributors to worsening lung function, impaired quality of life, emergency healthcare use and COPDrelated mortality. ${ }^{5}$ Regular use of inhaled corticosteroids (ICS), either alone or in combination with a longacting $\beta 2$-agonist ( $L A B A)$, reduces the risk of chronic obstructive pulmonary disease (COPD) exacerbation. These drugs are effective agents for the prevention of COPD exacerbations and improvement of lung function. They also have various effects on health status, but they are associated with adverse events, as pneumonia being the most concerning. ${ }^{6}$

Several recent studies have shown that blood eosinophil counts predict the magnitude of the effect of ICS (added on top of regular maintenance bronchodilator treatment) in preventing future exacerbation. Therefore, in Global Initiative for Chronic Obstructive Lung Disease
(GOLD) 2019, blood eosinophil counts can help clinicians estimate the likelihood of a beneficial preventive response to the addition of ICS to regular bronchodilator treatment, and thus can be used as a biomarker in conjunction with clinical assessment when making decisions regarding ICS use. $^{1}$

Indonesia do not yet have definitive data of COPD prevalence. The survey results of non-communicable diseases by the General Directorate of Eradication of Non-Communicable Diseases in five provincial hospitals in Indonesia (West Java, Central Java, East Java, Lampung, and South Sumatra) in 2004, COPD contributes at the most to morbidity (35\%), followed by bronchial asthma (33\%), lung cancer $(30 \%)$, and other $2 \% .^{7}$ As the GOLD 2019 application, this study aims to compare therapeutic data with blood eosinophil count in COPD patients.

\section{METHOD}

The research will be conducted in an observational descriptive from consecutive COPD outpatients in Bukit Asam Medika Hospital starting from March 1 $1^{\text {st }}, 2019$ until June 30 2019 and Dr. H. Mohamad Rabain Hospital starting from Oct $1^{\text {st }}, 2019$ until Dec $27^{\text {th }}, 2019$. 
Study participants will be patients suffering from COPD as defined by the Global Initiative for Chronic Obstructive Pulmonary Disease (GOLD) guidelines, ${ }^{1}$ more than $\geq 40$ years old, recruited from Bukit Asam Medika Hospital, Tanjung Enim, Muara Enim District, South Sumatra, Indonesia between 1 March until 30 June 2019 and Dr. H. Mohamad Rabain Hospital Muara Enim District, South Sumatra, Indonesia between 1 October until 27 December 2019. Patients will be excluded for refusal to participate, cannot perform spirometry, and unwilling or unable to provide informed consent.

The following data and measurements will be recorded:

- Demographics and anthropometrics, smoking history, and drug therapy.

- Dynamic lung volumes, assessed after bronchodilation and expressed as absolute and percent of predicted values according to The Pneumomobile Project Indonesia.

- The subjective sensation of breathlessness will be evaluated by means of the Medical Research Council (MRC) scale.

- Indonesian Version of the COPD Assessment Test (CAT) score.

- Blood eosinophil count.

\section{RESULT}

This study describes the main parameters namely therapeutic data and blood eosinophils in COPD patients, as well as several characteristics. These characteristics include gender, age, education, Brinkman index, duration of diagnosis, nutritional status (BMI), degree classification based on GOLD, and COPD group. There are 57 patients has been assessment. The characteristics of research subjects can be seen in Table 1.

The range age of the population was 55 until 64 years; approximately $96,5 \%$ of respondents were male. The most research population is junior high school education (33,3\%). Brinkman index of patients is dominated by moderate and heavy. Most of respondents were old patient. Respondents with body mass index underweight was $45,6 \%$ and normal weight was $43,9 \%$. Respondents with GOLD I, II, III, and IV constituted $7,0 \%, 36,8 \%, 38,6 \%$, and $17,5 \%$ of the population, respectively. Respondents in group $A$ same with group $B$ is $1,8 \%$ and groups C, D constituted $33,3 \%$ and $63,2 \%$ of the population, respectively. In blood eosinophil count $<300$ cells/ $\mu \mathrm{L}$ was $57,9 \%$. 
Table 1. Characteristics of COPD Patient

\begin{tabular}{|c|c|c|}
\hline Variable & Frequency & Percent \\
\hline \multicolumn{3}{|l|}{ Sex } \\
\hline Man & 55 & 96.5 \\
\hline Woman & 2 & 3.5 \\
\hline \multicolumn{3}{|l|}{ Age } \\
\hline $40-54$ & 13 & 22.8 \\
\hline $55-64$ & 25 & 43.9 \\
\hline $65-69$ & 10 & 17.5 \\
\hline$\geq 70$ & 9 & 15.8 \\
\hline \multicolumn{3}{|l|}{ Education } \\
\hline Uneducated & 14 & 24.6 \\
\hline Elementary School & 7 & 12.3 \\
\hline Junior High School & 19 & 33.3 \\
\hline Senior High School & 15 & 26.3 \\
\hline Diploma & 1 & 1.8 \\
\hline Master Degree & 1 & 1.8 \\
\hline \multicolumn{3}{|l|}{ Brinkman Index } \\
\hline Never & 5 & 8.8 \\
\hline Mild & 1 & 1.8 \\
\hline Moderate & 26 & 45.6 \\
\hline Heavy & 25 & 43.9 \\
\hline \multicolumn{3}{|l|}{ Duration of Diagnosis } \\
\hline New & 25 & 43.9 \\
\hline Old & 32 & 56.1 \\
\hline \multicolumn{3}{|l|}{ Body Mass Index } \\
\hline Underweight & 26 & 45.6 \\
\hline Normal weight & 25 & 43.9 \\
\hline Overweight & 5 & 8.8 \\
\hline Obesity & 1 & 1.8 \\
\hline \multicolumn{3}{|l|}{ GOLD } \\
\hline I & 4 & 7.0 \\
\hline II & 21 & 36.8 \\
\hline III & 22 & 38.6 \\
\hline IV & 10 & 17.5 \\
\hline \multicolumn{3}{|l|}{ COPD Group } \\
\hline$A$ & 1 & 1.8 \\
\hline B & 1 & 1.8 \\
\hline $\mathrm{C}$ & 19 & 33.3 \\
\hline$D$ & 36 & 63.2 \\
\hline
\end{tabular}


Table 1. Characteristics of COPD Patient (cont.)

\begin{tabular}{lcc}
\hline \multicolumn{1}{c}{ Variable } & Frequency & Percent \\
\hline Blood Eosinophil & 33 & 57.9 \\
$<300$ & 24 & 42.1 \\
$\geq 300$ & & \\
Drugs & 1 & 1.8 \\
SABA & 5 & 8.8 \\
LABA+ICS & 39 & 68.4 \\
SABA; LABA+ICS & 2 & 3.5 \\
SABA; LAMA & 2 & 3.5 \\
LAMA; LABA+ICS & 8 & 14.0 \\
SABA; LAMA; LABA+ICS & &
\end{tabular}

Table 2. Drugs and COPD Group Crosstabulation

\begin{tabular}{|c|c|c|c|}
\hline \multirow{2}{*}{ Drugs } & \multicolumn{2}{|c|}{ Blood Eosinophil } & \multirow{2}{*}{ Total } \\
\hline & $<300$ & $\geq \mathbf{3 0 0}$ & \\
\hline LABA+ICS & $2(6.1 \%)$ & $3(12.5 \%)$ & $5(8.8 \%)$ \\
\hline LAMA; LABA+ICS & $0(0.0 \%)$ & $2(8.3 \%)$ & $2(3.5 \%)$ \\
\hline SABA & $0(0.0 \%)$ & $1(4.2 \%)$ & $1(1.8 \%)$ \\
\hline SABA; LABA+ICS & $26(78.8 \%)$ & $13(54.2 \%)$ & $39(68.4 \%)$ \\
\hline SABA; LAMA & $0(0.0 \%)$ & $2(8.3 \%)$ & $2(3.5 \%)$ \\
\hline SABA; LAMA; LABA+ICS & $5(15.2 \%)$ & $3(12.5 \%)$ & $8(14.0 \%)$ \\
\hline Total & 33 (100.0\%) & $24(100.0 \%)$ & $57(100.0 \%)$ \\
\hline
\end{tabular}

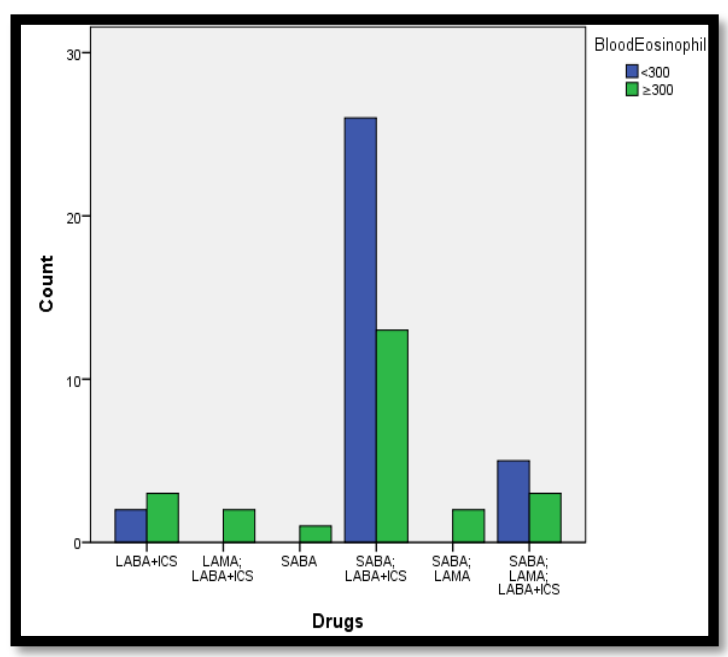

Graphic 1. Drugs Distribution by Blood Eosinophil Count

The proportions of COPD patients who had an inhaler drug are shown in Table 2.

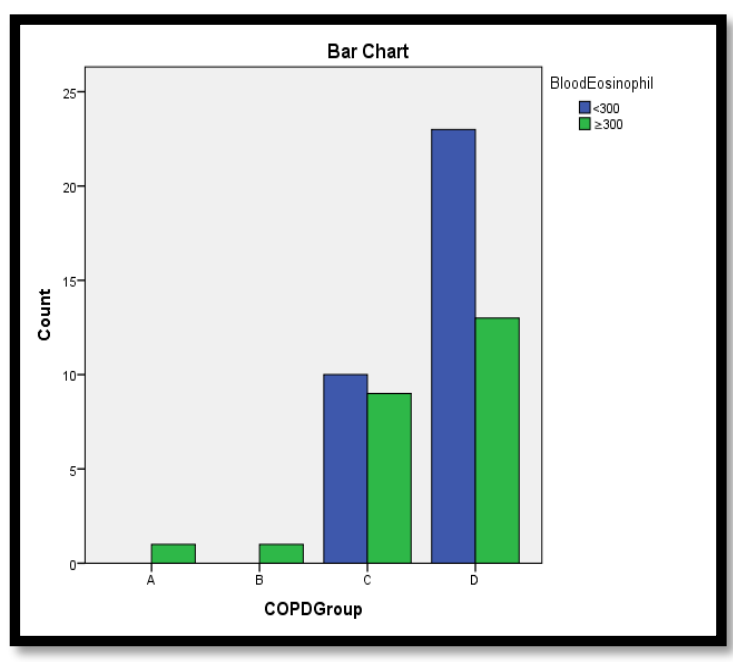

Graphic 2. Blood Eosinophil Count by COPD Group

In group $A$ there were 1 respondent $(2.9 \%)$ using SABA, and group B 1 (2.9\%) respondent using 
SABA; LABA + ICS. $10(29.4 \%)$ of respondents in group $C$ were divided into 7 respondents $(20.6 \%)$ using SABA; LABA + ICS, 2 (5.9\%) of respondents use SABA; LAMA, and 1 respondent $(2.9 \%)$ use triple therapy. Therapy in group $D$ is dominated by SABA; LABA + ICS were $16(47.1 \%)$ respondents while 6 (17.6\%) respondents used triple therapy. ICS is recommended in patients at high risk of exacerbations by the Global Initiative for COPD (GOLD) strategy. The highest use of ICS in group D was 22 respondents (64.7\%).

Comparison between ICS use and Blood Eosinophil Count can be seen in Graph 1. Respondents who received single ICS therapy is $3(60 \%)$ of 5 respondents and ICS in dual therapy is 15 (57.7\%) of 26 respondents who had a blood eosinophil count $\geq 300$ cells $/ \mu \mathrm{L}$. While respondents who received ICS in triple therapy with blood eosinophil count $\geq 300$ cells $/ \mu \mathrm{L}$ are $3(37.5 \%)$ of 8 respondents.

Graphic 2 shows the proportions of blood eosinophil count by COPD group patients. There was a higher proportion of respondents with blood eosinophil counts of $\geq 300$ cells $/ \mu \mathrm{L}$ in COPD Group D 13 (36,1\%) respondents. But compared with blood eosinophil count $<300$ cells $/ \mu \mathrm{L}$ in COPD Group $D$, higher than blood eosinophil counts of $\geq 300$ cells $/ \mu \mathrm{L}$ is $23(63,9 \%)$ respondent. The proportions of respondents with blood eosinophil counts of $\geq 300$ cells $/ \mu \mathrm{L}$ in COPD Group $A, B$, and $C$ were $1(4,2 \%)$ respondent, $1(4,2 \%)$ respondent, and $9(37,5 \%)$ respondent, respectively.

\section{DISCUSSION}

This study shows therapeutic data, blood eosinophils count, and several characteristics in COPD patients. These characteristics include gender, age, education, Brinkman index, duration of diagnosis, nutritional status (BMI), degree classification based on GOLD, and COPD group. The efficacy, safety and positioning of ICS in the treatment of patients with COPD is much debated, since it can result in clear clinical benefits in some patients ("friend") but can be ineffective or even associated with undesired side effects, e.g. pneumonia, in others ("foe"). ${ }^{8}$

The use of blood eosinophils as a biomarker in COPD is based on the premise that they reflect and correlate with tissue eosinophilic inflammation in pulmonary airways and parenchyma. ${ }^{9}$ Post hoc and pre-specified analyses of chronic obstructive pulmonary disease (COPD) randomized controlled trials have shown that higher blood eosinophil counts predict greater 
inhaled corticosteroid (ICS) effects on exacerbation prevention. ${ }^{10}$ The clinical relevance of a blood eosinophil cut off in the management of COPD remains uncertain because blood eosinophils are not stable throughout the disease course. A recent publication reported that the association of higher eosinophil counts with exacerbations is not consistent. ${ }^{11}$

The rate of pneumonia was marginally higher in those with $<2 \%$ blood eosinophils than those with $\geq 2 \%$ blood eosinophils, echoing findings from a post hoc analysis that suggested rates of pneumonia were slightly lower in patients with COPD with higher eosinophil counts and putatively more responsive to ICS. ${ }^{1,12}$ The threshold of a blood eosinophil count $>300$ cells $/ \mu \mathrm{L}$ identifies the top of the continuous relationship between eosinophils and ICS, and can be used to identify patients with the greatest likelihood of treatment benefit with ICS. ${ }^{1}$ The IMPACT trial and observational study in UK and US patients with COPD shows that assessment of blood eosinophil count and smoking status has the potential to optimize ICS use in clinical practice in patients with COPD and a history of exacerbations and should be considered while making treatment decisions. ${ }^{13,14}$
The use of blood eosinophil counts to predict ICS effects should always be combined with clinical assessment of exacerbation risk (as indicated by the previous history of exacerbations). Other factors (smoking status, ethnicity, geographical location) could influence the relationship between ICS effect and blood eosinophil count, but remains to be further explored. The mechanism for an increased ICS effect in COPD patients with higher blood eosinophil counts remains unclear. There is insufficient evidence to recommend that blood eosinophils should be used to predict future exacerbation risk on an individual basis in COPD patients. ${ }^{1}$

The problem in Indonesia regarding inhalation therapy in COPD patients is the high price of inhalation drugs. Although that has been helped by the national health insurance system, for LAMA inhalation is still relatively expensive, therefore the regulation of its administration is very difficult. Based on the GOLD COPD 2019 therapy algorithm, LAMA is the first choice in COPD group C and D therapy. While the administration of LABA + ICS therapy is only in COPD group $D$ by considering blood eosinophil count. 


\section{CONCLUSION}

This study may provide information and characteristic of COPD patient in Indonesia rural area and showed who may have benefit to ICS therapy based on recommendation GOLD COPD 2019. Blood eosinophils counts is a low-cost biomarker and may help clinicians to made decision therapy.

\section{REFERENCES}

1. The Global Initiative for Chronic Obstructive Lung Disease (GOLD). Global strategy for prevention, diagnosis and management of COPD 2019. Published 2019. Accessed January 5, 2019. http://goldcopd.org/goldreports/.

2. Lozano R, Naghavi M, Foreman $K$, et al. Global and regional mortality from 235 causes of death for 20 age groups in 1990 and 2010: A systematic analysis for the Global Burden of Disease Study 2010. Lancet. 2012;380(9859):20952128.

3. Mathers CD, Loncar D. Projections of global mortality and burden of disease from 2002 to 2030. PLoS Med. 2006;3(11):2011-2030.

4. Soriano JB, Abajobir AA, Abate $\mathrm{KH}$, et al. Global, regional, and national deaths, prevalence, disability-adjusted life years, and years lived with disability for chronic obstructive pulmonary disease and asthma, 1990-2015: a systematic analysis for the Global Burden of Disease Study 2015. Lancet Respir Med. 2017;5(9):691-706.

5. Kerkhof M, Sonnappa S, Postma DS, et al. Blood eosinophil count and exacerbation risk in patients with COPD. Eur Respir J. 2017;50(1).

6. Rabe KF, Beghé $B$, Fabbri LM. Peripheral eosinophil count as a biomarker for the management of COPD: not there yet. Eur Respir J. 2017;50(5).

7. PDPI. PPOK (Penyakit Paru Obstruktif Kronik) Diagnosis Dan Penatalaksanaan. PDPI; 2016.

8. Agusti A, Fabbri LM, Singh D, et al. Inhaled corticosteroids in COPD: Friend or foe? Eur Respir J. 2018;52(6).

9. Turato G, Semenzato U, Bazzan E, et al. Blood eosinophilia neither reflects tissue eosinophils nor worsens clinical outcomes in chronic obstructive pulmonary disease. Am J Respir Crit Care Med. 2018;197(9):1216-1219.

10. Southworth T, Beech G, Foden P, Kolsum U, Singh D. The 
reproducibility of COPD blood eosinophil counts. Eur Respir J. 2018;52(1).

11. Papi A, Kostikas K, Wedzicha JA, et al. Dual bronchodilation response by exacerbation history and eosinophilia in the FLAME Study. Am J Respir Crit Care Med. 2018;197(9):1223-1226.

12. Roche $\mathrm{N}$, Chapman KR, Vogelmeier $\mathrm{CF}$, et al. Blood eosinophils and response to maintenance chronic obstructive pulmonary disease treatment data from the FLAME Trial. Am J Respir Crit Care Med. 2017;195(9):11891197.

13. Pascoe $S$, Barnes N, Brusselle G, et al. Blood eosinophils and treatment response with triple and dual combination therapy in chronic obstructive pulmonary disease: analysis of the IMPACT trial. Lancet Respir Med. 2019;7(9):745-756.

14. Vogelmeier CF, Kostikas K, Fang J, et al. Evaluation of exacerbations and blood eosinophils in UK and US COPD populations. Respir Res. 2019;20(1):178. 